\title{
Attitudes of Jordanian Students Towards Using Group Work in EFL Classrooms
}

\author{
Sana' Ababneh \\ Al-Balqa' Applied University, Al-Huson University College, Jordan \\ E-mail: sanabneh@yahoo.com
}

Doi:10.7575/aiac.alls.v.8n.1p.233

Received: 18/12/2016

URL: http://dx.doi.org/10.7575/aiac.alls.v.8n.1p.233

Accepted: 25/02/2017

\begin{abstract}
This paper addresses itself to the outcomes of a field study which was carried out to identify Jordanian EFL students' attitudes towards using group work in EFL classrooms. The study sample consisted of 179 students enrolled in English 101, an elementary language skills course taught at Al- Huson University College, Al -Balqa' Applied University, Jordan. A questionnaire was used to investigate the subjects' attitudes. The findings show that approximately two-thirds of the participants are either very extrovert or somewhat extrovert, i.e. they have positive attitudes towards participating in group work in EFL classes. In contrast, only a third are either somewhat introvert or very introvert, i.e., they do not like to take part in group work in EFL classes. Moreover, the data show that neither the subjects' gender nor their secondary school stream (vocational, scientific, or literary) has any significant effect on their preferences.
\end{abstract}

Keywords: English, group work, attitudes, gender, Jordanian EFL learners

\section{Introduction}

Language is a means of communication between people who share a common code, their mother tongue (L1), through which they exchange messages, i.e., send ideas from one head to another (or others) and express their feelings concerning their life experiences. Most people acquire this L1 from their social environment (family, peers, etc.). In contrast, learning a foreign language (L2) is more difficult because the opportunity to practice it in real life situations is not the same as it is in the case of L1; most of the time, one is not given the same chance of using L2 because it is not the usual means of communication used by the people around him/her.

The differences between the two in the circumstances of use and acquisition raises questions about learners' attitudes towards the process of learning and, later, the actual use of L2. Brown (2002: 62) asserts that people vary in their attitudes towards communicating with others either in L1 or in L2 as some of them are introvert who do not like to meet other people or even work in groups, while others are extrovert who enjoy working in groups and communicating with others. Some learners, especially adults, prefer to work alone by habit since that is what they are used to do since they were young. But in such situations the task of teachers is to persuade such learners that language is a means of communicating with others and that the more they get into face-to-face interaction, the more they will improve in using the language properly (Brown 2001: 181). Language is a social phenomenon shared by a group of people and is useful in getting in touch with others. Working in groups is a simulated version of real life situations since real life involves working with others.

Due to the importance of this social aspect of language use, language teachers cannot ignore it. It is essential to incorporate it in our classes and encourage our students to get the best out of it. This is probably in line with Kramsch's (1992) opinion who states that "traditional forms of classroom interaction need to be reassessed in the light of the new language to help learners move from institutional productivity to productive conviviality" (p.28). In the same vein, Ramírez Salas asserts that

Group work helps students and teachers to bridge the gap between input and output. In other words, students show what they have learned by playing and using language with their peers. They also have the chance to have a small piece of reality in their classes by negotiating, turn-taking, suggesting, and getting to a final result. This is what human beings do every day, so why don't we bring that into our language classes too? $(2005$, p. 13)

Group work, according to Brown (2001: 177), is a "a generic term covering a multiplicity of techniques in which two or more students are assigned a task that involves collaboration and self-initiated language." He emphasizes the fact that it "implies 'small'-group work, that is, students in groups of perhaps six or fewer. Large groups defeat one of the main goals of using group work which is giving the students the opportunity to speak.".

According to Brown (ibid.: 178), group work has a number of advantages in the language classroom. First, it helps in generating interactive language as teachers no longer play the dominant role in the class and it helps them overcome the problem of large classes by giving more students the chance to speak. Second, group work provides an embracing 
climate for the students as they do not need to address all the class but only their small group of colleagues. Finally, group work encourages students to be more responsible and autonomous because there is no way for the learner to depend on other students to take his part in the task. Thus group work plays a major role in helping learners become more interactive and socialized in the language classroom.

To sum up, it is tempting to believe with Pishghadam \& Moghaddam (2011: 629) that "with all its advantages and disadvantages, group work is a precious instrument which can bring variety and fun to the class.".

\section{Significance of the study}

This study acknowledges the importance of English as an international language which has gained increasing attention from Jordanian educational institutions at different levels. Jordanian students start learning English from the first grade which means that they are exposed to at least twelve years of English learning experience by the time they graduate from secondary school. At the university level, general English is an obligatory university requirement and, for some study majors, a faculty requirement as well. Moreover, the medium of instruction in many subjects, such as medicine, technology, engineering, and science at university level is English (Carkin, 2005). Nevertheless, neither Jordanian students' performance on English exams, nor their ability to use the language in real communication is satisfactory.

This study is an attempt to investigate Jordanian EFL students' attitudes towards using group work in English classrooms. Moreover, it aims at exploring whether there is a relationship between students' attitudes on the one hand and their gender and their stream in the secondary school on the other.

\subsection{Questions of the study}

The present study aims to answer the following questions:

1. What are Jordanian EFL students' attitudes towards using group work in EFL classroom?

2. Are there any significant differences between the participants' attitudes towards using group work in the EFL classroom due to gender?

3. Are there any significant differences between the participants' attitudes towards using group work in EFL classroom due to their secondary school stream?

\section{Review of related literature}

The use of group work in classroom activities is a teaching method that is used to increase learning motivation and to decrease the anxiety or the fear of facing the whole class. This fear and this anxiety are felt especially by some students who are shy or less confident. There are many studies in the fields of TEFL and TESL that address this topic because of its great importance. One interesting related study conducted by Taqi and Al-Nouh (2014) investigated the advantages of using group work in English exams. The study revealed that most students felt that they enjoyed the tasks and would like to work in a group more often. The method of forming a group also seemed to affect learning. It was found that social and academic variables of age and GPA affected the formation, engagement and results of group work. Another interesting study by Pishghadam \& Moghaddam (2011) investigated the role of group work among children in EFL classes in order to examine the effect of group work on the language performance of children. The study showed that the children who were taught using group work method enjoyed considerable advantages, especially in memorizing conversations and learning new vocabulary.

Rahaman (2014) studied the effect of using group work on reading skills in EFL classes. Findings of this study showed that teaching text reading comprehension through group work might be effective in secondary school. The study emphasized the importance of training teachers in implementing group work activities. It also claimed that text reading could be more useful due to sharing ideas and socializing through group work which should make the classroom student-centered and give the learners the opportunity to feel free and have the chance to observe their own improvement within a friendly environment.

Othman \& Murad (2015) conducted a study aimed at identifying the different opinions of Kurdish students concerning the advantages and disadvantages of group work in the classroom. The findings revealed both positive and negative opinions. Amongst the advantages of using group work, the participants claimed that group members clarified difficult things to each other. Moreover, a given task took less time to finish in group work. While the negative opinions according to them were the tendency of some members to relax and remain silent and not to work at all as they depended on others to do all the work.

\section{Methodology}

\subsection{Participants of the study}

The participants of the present study were purposefully chosen from the students registered in the second semester of the academic year 2015/2016 in English 101, a course of English language skills given at Al- Huson University College. The total number of the participants was 179. There were 119 male students and 60 female students. The participants were asked to identify their stream at the secondary school (Vocational, Scientific, or Literary). About two thirds $(64.2 \%)$ come from the vocational stream. Table 1 shows the demographic distribution of the participants. 
Table 1. Numbers and Percentages of Participants' Gender and Secondary School Stream

\begin{tabular}{ccccc}
\hline Variable & & Number & $\%$ \\
\hline \multirow{3}{*}{ Gender } & Male & 119 & 66.5 \\
\cline { 2 - 4 } & Female & 60 & 33.5 \\
\cline { 2 - 4 } & Total & 179 & 100.0 \\
\cline { 2 - 4 } & Vocational & 115 & 64.2 \\
\cline { 2 - 4 } Secondary School Stream & Scientific & 49 & 27.4 \\
\cline { 2 - 4 } & Literary & 15 & 8.4 \\
\cline { 2 - 4 } & Total & 179 & 100.0 \\
\cline { 2 - 4 } & & & &
\end{tabular}

\subsection{Instrument of the Study}

The primary method of inquiry used in this study is a questionnaire adopted from Brown (2002: 61). The questionnaire consists of ten incomplete statements which the participants are asked to complete in either of two ways by checking the (a) distracter or the (b) distracter. The (a) distracters are worded to reflect an extrovert attitude; the (b) ones, introvert. An (a) response was given one point, while a(b) got a zero. Eight to nine points were interpreted to reflect a very extrovert character; 6-7, somewhat extrovert; 3-5, somewhat introvert; 0-2 very introvert.

\subsection{Data Collection}

The researcher of this study is one of the instructors of English at the College. The students were informed of the objectives and significance of the study. They were also requested to state their honest and true responses. Furthermore, the researcher answered all the participants' inquiries about the questionnaire statements to ensure that they give true responses.

\subsection{Data Analysis}

This study basically sought to identify Jordanian EFL students' attitudes towards group work in EFL classroom. Thus the data collected from their responses were analyzed in terms of means, using the Statistical Package for Social Sciences (SPSS), and the percentages were also computed. In order to investigate if there are any significant relationships between the participants' attitudes on one hand and their gender or stream at the secondary school, Pearson correlation and ANOVA tests were used.

\section{Findings and Discussion}

The first question of the study aimed to explore the attitudes of Jordanian students towards using group work in EFL classes. To answer this question the researcher analyzed the participants' responses to the Questionnaire statements which reflect whether a respondent is an introvert, i.e., has negative attitudes towards using group work or he/she is an extrovert, i.e., has a positive attitude towards using group work. Table (2) presents the percentages of students' responses to the Questionnaire statements that reflect their attitudes towards using group work in EFL classroom.

Table 2. Results of Students' Attitudes Towards Using Group Work in EFL Classrooms

\begin{tabular}{lcc}
\hline Attitude & $\begin{array}{c}\text { Number of } \\
\text { Students }\end{array}$ & $\%$ \\
\hline Very Extrovert & 16 & 8.9 \\
\hline Somewhat Extrovert & 97 & 54.2 \\
\hline Somewhat Introvert & 60 & 33.5 \\
\hline Very Introvert & 6 & 3.4 \\
\hline Total & $\mathbf{1 7 9}$ & $\mathbf{1 0 0 . 0}$ \\
\hline
\end{tabular}

This table shows that about two-thirds of the participants are either very extrovert or somewhat extrovert. In other words, the majority of the participants should be expected to show a positive attitude towards group work.

The second question was intended to investigate if the gender of the participants has a significant effect on their attitudes towards using group work in English classroom. To answer this question, a $t$-test for equality to the mean scores of the participants' responses was computed. Table 3 shows the results.

Table 3. Mean Scores and T-test of Students' Responses to the Questionnaire According to Their Gender

\begin{tabular}{ccccc}
\hline Gender & Mean scores & $\begin{array}{c}\text { Standard } \\
\text { deviation }\end{array}$ & $\mathrm{T}$ & Sig \\
\hline Male & 5.98 & 1.85 & 0.39 & 0.69 \\
\hline Female & 6.10 & 1.95 & & \\
\hline
\end{tabular}


Results obtained from Table 3 show that the there are no significant differences between the participants' responses that could be attributed to the difference in their gender since the $T$ value at $(a \leq 0.05)$ was $(0.39)$.

The third question examined the effect of the participants' secondary school stream on their attitudes towards using group work in English classroom. In order to answer this question ANOVA test of variance was applied to their responses to see if it has an effect on their attitudes. Table 4 presents the results.

Table 4. Results of ANOVA Test of the Mean Scores of the Participants' Responses

According to their Secondary School Stream

\begin{tabular}{cllll}
\hline Secondary School Stream & Mean scores & $\begin{array}{l}\text { Standard } \\
\text { deviation }\end{array}$ & F & Sig \\
\cline { 1 - 3 } & \multirow{2}{*}{1.31} & 0.27 \\
\hline Vocational & 6.16 & 1.71 & & \\
\hline Scientific & 5.65 & 2.24 & & \\
\hline Literary & 6.20 & 1.78 & &
\end{tabular}

Results obtained from Table 4 show that there are no significant differences between the participants' responses to the Questionnaire that could be attributed to their different streams at the secondary school level, since the $F$ value for the participants' responses was (1.31).

\section{Conclusions and Recommendations}

From the above discussion it can be concluded that the participants in this study displayed a moderately positive attitude towards using group work in their English classrooms. The results may be considered as a call for English teachers to shed their fear of using group work in their classes. Such fear is usually the result of having big classes, losing control of their classes, or worrying about the use of L1 by the students who would revert to their mother tongue whenever they have a chance to do so. Teachers are advised to implement group work in spite of these fears.

Group work has proven to possess a lot of benefits for the teaching/learning process since it generates interactive language learning atmosphere, offers a secure climate for students to speak freely in their small groups, and promotes students' responsibility and autonomy (Brown, 2001: 178). This is also supported by Jiang (2009: 138) who concludes that "well-organized group work is an efficient means to improve language teaching, especially college English teaching. By means of group work, students' linguistic competence and the ability to make use of new knowledge will be strengthened".

Another conclusion drawn from this study is that the participants' gender does not have a significant effect on their attitudes towards using group work. Both male and female participants responded almost positively towards the use of group work in their English classes. This could be due to the fact that both male and female students suffer from the same problems and are exposed to the same conditions in their classrooms.

Finally, it is obvious that the participants' school stream in their secondary school has no significant effect on their attitudes. Whatever difference there is between the two is not reflected in their relation to English: they are exposed to the same syllabus, the same classroom conditions and the same set of motivations. Therefore, their attitudes are more or less the same.

Based on the above conclusions, it is recommended to implement group work strategies in Jordanian EFL classrooms although there are many factors that may stand in the way of such implementation: many Jordanian classes are large containing 40 students or more per section, most EFL classroom activities are teacher-centered and the quality and amount of students' participation in EFL classes is unfortunately limited. But due to the importance of using group work in improving students' ability to use the language and to encourage them overcome their shyness or fear of confronting their peers by dividing them in small groups, group work implementation requires from us teachers to have enough confidence in it.

It is also recommended to conduct a similar study with a larger sample representing all Jordanian universities since the subjects of the present study come from Al-Balqa' Applied University only-- a matter that might affect the reliability of the results.

\section{References}

Brown, D. (2001). Teaching by Principles: an interactive approach to language pedagogy. N Y: Longman.

Brown, H. D. (2002). Strategies for Success: A practical Guide to Learning English. White Plains, NY: Longman.

Carkin, S. (2005). English for academic purposes. In E. Henkel (Ed). A Handbook of Research in Second Language Teaching and Learning (pp. 85-98). NewJersy: Lawrence Elbaum Association, Inc.

Jiang, Y. (2009). Applying Group Work to Improve College Students' Oral English. International Education Studies, $3(2), 136-139)$. 
Kramsch, C. (1992). Interactive discourse in small and large groups. In W. Rivers (Ed.), Interactive Language Teaching. New York: Cambridge University Press. 17-30.

Othman, H. G. \& Murad, I. H. (2015). A Study on Kurdish Students' Attitudes to Group Work in the EFL Classroom. European Scientific Journal , 11(11).

Pishghadam, R. \& Moghaddam, M. M. (2011). Group Work in EFL Children's Classes: A Qualitative Study. Theory and Practice in Language Studies, 1(6), pp. 622-629.

Rahaman, A. (2014). Reading comprehension through group work activities in an EFL classroom: An action research report. Working Papers on Culture, Education and Human Development, 10(2), 1-8.

http://www.uam.es/otros/ptcedh/2014v10_pdf/v10n2eng.pdf

Ramírez Salas, Marlene. (2005). Grouping techniques in an EFL classroom. Revista Electrónica "Actualidades Investigativas en Educación", 5, 1-14.

Taqi, Hanan, A. \& Al-Nouh, Nowreyah, A. (2014). Effect of Group Work on EFL Students' Attitudes and Learning in Higher Education. Journal of Education and Learning; Vol. 3, No. 2.

Gender: Male / Female

Secondary school stream: Vocational / Scientific / Literary

Choose the statement ( $\mathbf{a} / \mathbf{b})$ that best describes you.

1. In the classroom. I

a. ask the teacher a lot of questions.

b. hardly ever ask the teacher a question.

2. I usually like

a. working with other people.

b. working alone.

3. I am

a. easy for people to talk with.

b. somewhat shy.

4. I am happiest when I'm

a. with other people.

b. alone.

5. At a party, I ......

a. start conversations with people I don't know.

b. wait for someone to talk with me.

6. I solve problems better by

a. talking with others about it.

b. analyzing them on my own.

7. In my free time, I prefer to .....

a. go out with other people.

b. stay at home by myself.

8. Talking with people I don't know is...

a. interesting and exciting.

b. difficult and makes me tired.

9. When I'm by myself I usually feel........ a. lonely and anxious.

b. peaceful and calm.

10. In a classroom I prefer

a. group work with other students.

b. individual work on my own.

\section{Thank You!}

